\title{
Karakterisasi Morfologi Anggrek Phalaenopsis spp. Spesies Asli Indonesia
}

\author{
Morphology Characterization of Indonesia Phalaenopsis spp. Species
}

\author{
Ni’mah Fauziah, Sandra Arifin Aziz", Dewi Sukma
}

Departemen Agronomi dan Hortikultura, Fakultas Pertanian, Institut Pertanian Bogor

(Bogor Agricultural University), Jl. Meranti, Kampus IPB Darmaga, Bogor 16680, Indonesia

Telp.\&Faks.62-251-8629353 e-mail agronipb@indo.net.id

*)Penulis untuk korespondensi : $\underline{\text { sandraaziz@yahoo.com }}$

Disetujui 24 Desember 2013/ Published online 13 Februari 2014

\begin{abstract}
The existence of Phalaenopsis orchid species had declined, so efforts should be made to preserve the species. Crosses through artificial propagation effort is an attempt to produce a better crop than the parent, but it often fails because of incompatibity of the parent. This could be minimized by performing characterization to determine the relationship between parental crosses. The purpose of this research was to study the morphological characters of 14 accessions of the Phalaenopsis orchid species i.e, Phalaenopsis gigantea A (PGA), Phalaenopsis bellina (PB), Phalaenopsis amabilis Halong (PAH), Phalaenopsis violacea $(P V)$, Phalaenopsis doritis (PD), Phalaenopsis schilleriana (PS), Phalaenopsis modesta (PM), Phalaenopsis cornu-cervi (PC), Phalaenopsis pantherina (PP), Phalaenopsis tetraspis (PT), Phalaenopsis pulchra (PPA), Phalaenopsis amabilis Cidaun (PAC), Phalaenopsis amabilis Treanggalek (PAT) and Phalaenopsis gigantea $B(P G B)$. The results showed that each member of each accession in Phalaenopsis species have a very close kinship that is $100 \%$, except Phalaenopsis tetraspis $87 \%$ relation due to the different tip shape of the leaves, Phalaenopsis gigantea A with Phalaenopsis bellina (87\%), Phalaenopsis amabilis with Phalaenopsis gigantea B (87\%), Phalaenopsis violacea with Phalaenopsis pulchra (87\%) and Phalaenopsis amabilis Halong with Phalaenopsis pantherina (87\% ). Based on the flower classification, Phalaenopsis violacea and Phalaenopsis modesta (78\%) has close kinship. While the classification based on leaf and flower, showed that Phalaenopsis violacea and Phalaenopsis modesta had close kinship of $70 \%$.
\end{abstract}

Keywords: kinship, Phalaenopsis orchid species

\section{ABSTRAK}

Keberadaan anggrek Phalaenopsis spesies atau anggrek hutan sudah semakin menurun, sehingga perlu dilakukan upaya perbanyakan untuk melestarikannya. Upaya perbanyakan melalui persilangan buatan merupakan salah satu upaya untuk menghasilkan tanaman yang lebih baik dari tetuanya, namun sering mengalami kegagalan akibat incompatibitas tetua. Hal tersebut dapat dikurangi dengan melakukan karakterisasi untuk mengetahui kekerabatan antar tetua persilangan. Tujuan dari penelitian ini adalah untuk mempelajari karakter morfologi 14 aksesi anggrek Phalaenopsis spesies yaitu Phalaenopsis gigantea A $(P G A)$, Phalaenopsis bellina (PB), Phalaenopsis amabilis Halong (PAH), Phalaenopsis violacea (PV), Phalaenopsis doritis (PD), Phalaenopsis schilleriana (PS), Phalaenopsis modesta (PM), Phalaenopsis cornu-cervi (PC), Phalaenopsis pantherina (PP), Phalaenopsis tetraspis (PT), Phalaenopsis pulchra (PPA), Phalaenopsis amabilis Cidaun (PAC), Phalaenopsis amabilis Trenggalek (PAT) dan Phalaenopsis gigantea $B(P G B)$. Hasil penelitian menunjukkan setiap anggota masing-masing aksesi pada Phalaenopsis spesies memiliki kekerabatan sangat dekat yaitu 100\% kecuali Phalaenopsis tetraspis yang berkerabat $87 \%$ akibat perbedaan bentuk ujung daun. Berdasarkan klasifikasi daun aksesi yang berkerabat dekat adalah Phalaenopsis gigantea A dengan Phalaenopsis bellina (87\%), Phalaenopsis amabilis Trenggalek dengan Phalaenopsis gigantea B (87\%), Phalaenopsis violacea dengan Phalaenopsis pulchra (87\%) dan Phalaenopsis amabilis Halong dengan Phalaenopsis pantherina (87\%). Berdasarkan klasifikasi bunga aksesi yang memiliki kekerabatan dekat adalah Phalaenopsis violacea dengan Phalaenopsis modesta (78\%). 
Berdasarkan klasifikasi daun dan bunga aksesi yang berkerabat dekat adalah Phalaenopsis violacea dengan Phalaenopsis modesta (70\%).

Kata kunci: kekerabatan, anggrek Phalaenopsis spesies

\section{PENDAHULUAN}

Anggrek termasuk dalam famili orchidaceae yang mempunyai 800 genera dan 25000 spesies. Tanaman ini terdiri dari tanaman monokotil, herba dan tahunan. Daya tarik tanaman anggrek adalah keindahan bentuk bunga dan warna yang beraneka ragam sehingga tidak menimbulkan rasa bosan bagi pecintanya (Mattjik 2010).

Salah satu jenis anggrek yang populer adalah genus Phalaenopsis atau lebih dikenal dengan anggrek bulan. Kekhasan Phalaenopsis adalah bentuk bunganya yang lebih besar dengan warna yang bervariasi dan panjang mekar bunga yang lebih lama dibandingkan jenis anggrek lain. Keindahan Phalaenopsis tidak diikuti dengan ketersediaannya di alam. Keberadaaan Phalaenopsis atau anggrek bulan semakin jarang, sehingga perlu dilakukan tindakan perbanyakan untuk melestarikannya (Jenny et al. 2009).

Perbanyakan anggrek dapat dilakukan secara alami melalui perbanyakan vegetatif maupun generatif. Selain perbanyakan secara alami, dapat pula dilakukan perbanyakan dengan campur tangan manusia (Matjik 2010). Salah satu proses perkembangbiakan yang melibatkan manusia adalah persilangan buatan. Keunggulan dari teknik persilangan buatan adalah dapat memadukan beberapa sifat unggul dari dua genotipe yang disilangkan, sehingga dapat dihasilkan tanaman baru yang memiliki sifat unggul tetuanya. Persilangan buatan tidak selalu menghasilkan tanaman yang unggul, karena dalam prosesnya sering terjadi kegagalan. Kegagalan dalam persilangan dapat diminimalisasi dengan mengetahui terlebih dulu karakter morfologi dari masing-masing genotipe yang akan disilangkan. Karakter morfologi tersebut dapat dijadikan penduga hubungan kekerabatan antar genotipe yang akan dijadikan tetua, sehingga persilangan dapat dilakukan dan menghasilkan tanaman baru yang lebih baik (Purwantoro et al. 2005). Penelitian ini bertujuan untuk menjajaki karakter morfologi beberapa anggrek Phalaenopsis spesies asli dan melakukan pendugaan hubungan kekerabatannya.

\section{BAHAN DAN METODE}

Penelitian dilaksanakan di Screen house Gunung Batu Bogor dan Micro Technique Laboratory Departemen Agronomi dan Hortikultura, IPB pada bulan Oktober 2012 - April 2013. Bahan tanaman yang digunakan dalam penelitian ini adalah 14 aksesi anggrek Phalaenopsis spesies asli yaitu: Ph. gigantea A (PGA) dengan ukuran daun besar, Ph. bellina (PB), Ph. amabilis Halong (PAH), Ph. violacea (PV), Ph. doritis (PD), Ph. schilleriana (PS), Ph. modesta (PM), Ph. cornu-cervi (PC), Ph. pantherina (PP), Ph. tetraspis (PT), Ph. pulchra (PPA), Ph. amabilis Cidaun (PAC), Phalaenopsis amabilis Treanggalek (PAT) dan Ph. gigantea B (PGB) dengan ukuran daun kecil. Peralatan yang digunakan adalah alat ukur (meteran dan jangka sorong) dan mikroskop.

Parameter yang diamati dibedakan menjadi kualitatif dan kuantitatif. Parameter kualitatif yang diamati yaitu: keragaan umum (tipe pertumbuhan dan penampang melintang daun), daun (bentuk daun, bentuk ujung daun, susunan daun dan simetri daun), bunga (tipe pembungaan, bentuk bunga, bentuk sepal, bentuk petal, penampang melintang dan membujur sepal dan petal), keragaan khusus Phalaenopsis (susunan petal dan bentuk keping tengah bibir). Parameter kuantitatif yang diamati yaitu: jumlah daun, panjang daun, lebar daun, panjang bunga, lebar bunga, panjang sepal dan petal serta lebar sepal dan petal. Pengamatan anatomi daun dilakukan terhadap jumlah stomata, ukuran stomata dan kerapatan stomata. Anatomi daun diamati secara destruktif pada permukaan bagian bawah daun yang telah membuka sempurna (daun ke 3-5).

Data kuantitatif yang diperoleh dianalisis menggunakan uji t-dunnet dengan Phalaenopsis amabilis Cidaun sebagai kontrol. Data kualitatif dianalisis menggunakan analisis gerombol untuk mengetahui hubungan kekerabatan antar spesies dengan menggunakan software NTSYS-PC yang selanjutnya tersaji dalam bentuk dendogram berdasarkan klasifikasi daun, bunga dan gabungan daun dan bunga 


\section{HASIL DAN PEMBAHASAN}

\section{Data Kuantitatif}

\section{Jumlah Daun, Panjang Daun dan Lebar Daun}

Data kuantitatif karakter morfologi daun terdiri dari jumlah daun, panjang daun dan lebar daun. Hasil uji t-dunnett dengan Phalaenopsis amabilis Cidaun sebagai kontrol disajikan pada Tabel 1. Hasil uji statistik menunjukkan bahwa terdapat keragaman jumlah daun, panjang daun dan lebar daun pada anggrek Phalaenopsis spesies. Jumlah daun terbanyak diantara 14 aksesi anggrek yang diamati adalah $P h$. doritis, namun jumlah daun semua aksesi yang diamati tidak berbeda nyata dengan kontrol.

Panjang daun tertinggi memiliki nilai 33.40 $\mathrm{cm}$ yaitu pada aksesi Ph. amabilis Trenggalek, namun aksesi ini tidak berbeda nyata dengan kontrol. Aksesi lain yang tidak berbeda nyata dengan kontrol adalah $P h$. gigantea A.

Tabel 1. Rata-rata jumlah daun, panjang daun dan lebar daun beberapa aksesi anggrek Phalaenopsis spesies

\begin{tabular}{lccc}
\hline \multirow{2}{*}{ Aksesi } & Jumlah daun $^{\mathrm{a}}$ & Panjang daun $^{\mathrm{a}}$ & Lebar daun $^{\mathrm{a}}$ \\
\cline { 3 - 4 } & & $\ldots \ldots \ldots \ldots \ldots \ldots \ldots \ldots \ldots \ldots \ldots \ldots \ldots \ldots \ldots \ldots \ldots \ldots \ldots \ldots \ldots \ldots \ldots \ldots \ldots \ldots$ \\
Phalaenopsis gigantea $\mathrm{A}$ & $2.6 \mathrm{a}$ & $23.84 \mathrm{a}$ & 9.24 \\
Phalaenopsis bellina & $3.8 \mathrm{a}$ & 20.08 & $7.86 \mathrm{a}$ \\
Phalaenopsis amabilis $\mathrm{H}$. & $1.6 \mathrm{a}$ & 7.96 & 2.64 \\
Phalaenopsis violacea & $3.6 \mathrm{a}$ & 8.50 & 1.50 \\
Phalaenopsis doritis & $9.0 \mathrm{a}$ & 3.94 & 1.60 \\
Phalaenopsis schilleriana & $4.5 \mathrm{a}$ & 15.60 & $5.48 \mathrm{a}$ \\
Phalaenopsis modesta & $4.5 \mathrm{a}$ & 12.50 & 4.15 \\
Phalaenopsis cornu-cervi & $5.7 \mathrm{a}$ & 15.97 & 3.20 \\
Phalaenopsis pantherina & $4.8 \mathrm{a}$ & 16.52 & 3.48 \\
Phalaenopsis tetraspis & $4.2 \mathrm{a}$ & 15.86 & $6.58 \mathrm{a}$ \\
Phalaenopsis pulchra & $4.0 \mathrm{a}$ & 5.83 & 2.30 \\
Phalaenopsis amabilis Trenggalek & $7.4 \mathrm{a}$ & $33.40 \mathrm{a}$ & $7.28 \mathrm{a}$ \\
Phalaenopsis gigantea $\mathrm{B}$ & $3.8 \mathrm{a}$ & 12.36 & $4.88 \mathrm{a}$ \\
\hline Phalaenopsis amabilis Cidaun & $\mathbf{5 . 0 a}$ & $\mathbf{2 8 . 6 8 a}$ & $\mathbf{6 . 9 0 a}$ \\
\hline
\end{tabular}

a Angka-angka pada kolom yang sama yang diikuti oleh huruf yang sama menunjukkan hasil tidak berbeda nyata dengan kontrol pada uji t-dunnett taraf $\alpha 5 \%$

Daun terlebar dari 14 aksesi yang diamati adalah Ph. gigantea A dengan lebar daun $9.24 \mathrm{~cm}$ dan berbeda nyata dengan kontrol. Lebar daun pada 14 aksesi anggrek berbeda nyata dengan kontrol kecuali $P h$. bellina, $P h$. schilleriana, $P h$. tetraspis, Ph. amabilis Trenggalek dan $P h$. gigantea $\mathrm{B}$.

Nilai panjang dan lebar daun berkaitan dengan bentuk daun. Bentuk daun lonjong atau memanjang cenderung memiliki daun yang lebih panjang namun lebar lebih kecil, sedangkan aksesi yang memiliki bentuk daun membulat memiliki panjang daun yang lebih pendek dan lebar yang lebih besar.

\section{Panjang dan Lebar Bunga, Sepal dan Petal}

Hasil analisis statistik pada Tabel 2 menunjukkan bahwa panjang bunga 5 aksesi anggrek berbeda nyata dengan kontrol. Aksesi yang tidak berbeda nyata dengan kontrol adalah $P h$. violacea dan Ph. schilleriana. Bunga yang terpanjang adalah bunga $P h$. violacea yaitu 5.73 $\mathrm{cm}$. Hasil berbeda ditunjukkan pada lebar bunga, dimana seluruh aksesi memiliki nilai lebar bunga yang berbeda nyata dengan kontrol.

Panjang sepal dorsal 7 aksesi Phalaenopsis spesies tidak berbeda nyata dengan kontrol kecuali $P h$. modesta, sedangkan lebar sepal dorsal tidak berbeda nyata dengan kontrol pada semua aksesi. Phalaenopsis violacea memiliki panjang sepal lateral yang tidak berbeda nyata dengan kontrol, namun 6 aksesi lainnya berbeda nyata dengan kontrol. Hal ini dapat berkaitan dengan bentuk sepal lateral yang sama antara $P h$. violacea dengan $P h$. amabilis Cidaun sebagai kontrol. Kolom lebar sepal lateral menunjukkan bahwa Ph. cornu-cervi 
memiliki nilai yang berbeda nyata dengan kontrol dan aksesi lainnya.

Phalaenopsis amabilis Cidaun memiliki petal terpanjang diantara semua aksesi yaitu 3.70 $\mathrm{cm}$. Lebar petal $P h$. schilleriana merupakan nilai lebar tertinggi diantara semua aksesi dan berbeda nyata dengan kontrol. Phalaenopsis schilleriana memiliki petal yang lebih lebar dibandingkan dengan aksesi lain.

Menurut Fatimah (2010) dalam pemuliaan tanaman, Phalaenopsis amabilis dan Phalaenopsis schilleriana merupakan aksesi pada grup bunga besar (standard) dimana warna putih berasal dari Phalaenopsis amabilis dan warna pink berasal dari Phalaenopsis schilleriana.

Tabel 2. Rata-rata panjang dan lebar bunga, sepal dan petal beberapa aksesi anggrek Phalaenopsis spesies

\begin{tabular}{lcccccccc}
\hline \multirow{2}{*}{ Aksesi } & \multicolumn{2}{c}{ Bunga } & \multicolumn{2}{c}{ Sepal dorsal } & \multicolumn{3}{c}{ Sepal lateral } & \multicolumn{2}{c}{ Petal } \\
\cline { 2 - 9 } & Panjang & Lebar & Panjang & Lebar & Panjang & Lebar & Panjang & Lebar \\
\hline & $\ldots \ldots \ldots \ldots \ldots \ldots \ldots \ldots \ldots \ldots \ldots \ldots \ldots \ldots . \mathrm{cm} \ldots \ldots \ldots \ldots \ldots \ldots \ldots \ldots \ldots \ldots \ldots \ldots \ldots \ldots$ \\
Ph. gigantea $\mathrm{A}$ & 3.99 & 3.97 & $2.47 \mathrm{a}$ & 1.76 & 2.40 & $1.60 \mathrm{a}$ & 2.37 & 1.59 \\
Ph. bellina & 4.12 & 3.32 & $2.00 \mathrm{a}$ & 1.34 & 2.32 & $1.19 \mathrm{a}$ & 1.80 & 1.17 \\
Ph. violacea & $5.73 \mathrm{a}$ & 4.62 & $2.12 \mathrm{a}$ & 1.12 & $2.62 \mathrm{a}$ & $1.19 \mathrm{a}$ & 2.22 & 1.44 \\
Ph. schilleriana & $5.25 \mathrm{a}$ & 6.18 & $2.60 \mathrm{a}$ & 1.40 & 2.35 & $1.37 \mathrm{a}$ & 3.07 & $3.37 \mathrm{a}$ \\
Ph. modesta & 2.53 & 2.71 & 1.13 & 0.55 & 1.43 & $0.84 \mathrm{a}$ & 1.18 & 0.48 \\
Ph. cornu-cervi & 3.62 & 3.07 & $1.84 \mathrm{a}$ & 0.53 & 1.86 & 0.77 & 1.14 & 0.53 \\
Ph. tetraspis & 4.42 & 4.02 & $2.31 \mathrm{a}$ & 1 & 2.09 & $1.17 \mathrm{a}$ & 1.98 & 1.19 \\
\hline Ph. amabilis Cidaun & $\mathbf{5 . 7 0 a}$ & $\mathbf{7 . 4 0 a}$ & $\mathbf{3 . 1 0 a}$ & $\mathbf{1 . 3 a}$ & $\mathbf{3 . 1 5 a}$ & $\mathbf{1 . 4 0 a}$ & $\mathbf{3 . 7 0 a}$ & $\mathbf{3 . 1 3 a}$ \\
\hline
\end{tabular}

a Angka-angka pada kolom yang sama yang diikuti oleh huruf yang sama menunjukkan hasil tidak berbeda nyata dengan kontrol pada uji t-dunnett taraf $\alpha 5 \%$

\section{Data Kualitatif}

Data kualitatif diamati untuk mengetahui keragaman karakter morfologi 14 aksesi anggrek Phalaenopsis spesies dan melakukan pendugaan hubungan kekerabatannya. Pendugaan hubungan kekerabatan dilakukan dengan analisis gerombol berdasarkan klasifikasi daun, bunga serta daun dan bunga. Menurut Marzuki et al. (2008) karakterisasi tanaman pada tingkat morfologi diperlukan terutama untuk keperluan identifikasi fenotipe dan perubahannya terkait dengan ekotipe atau perubahan-perubahan lingkungan.

\section{Pendugaan Hubungan Kekerabatan Berdasarkan Morfologi Daun}

Kedekatan hubungan kekerabatan antar 14 aksesi anggrek Phalaenopsis spesies berdasarkan klasifikasi daun disajikan dalam bentuk dendogram (Gambar 1). Pendugaan hubungan kekerabatan dilakukan terhadap 67 tanaman dari 14 aksesi anggrek Phalaenopsis spesies. Tingkat kemiripan masing-masing individu ditunjukkan dengan jarak euclidius dengan koefisien mulai dari 0.00 sampai 1.00 .

Berdasarkan pengamatan terhadap variabel daun, anggrek Phalaenopsis spesies membentuk dua gerombol yaitu gerombol A dan gerombol B pada jarak euclidius 0.57 atau memiliki kemiripan sebesar 57\%. Gerombol A terdiri dari aksesi $P h$. gigantea A, Ph. bellina, Ph. tetraspis, Ph. amabilis Trenggalek dan $P h$. gigantea $\mathrm{B}$.

Aksesi pada gerombol A menggerombol berdasarkan kemiripan sifat morfologi yaitu susunan daun, bentuk tepi daun dan tekstur permukaan daun. Gerombol A kembali membentuk dua gerombol yaitu A1 dan A2 pada jarak euclidius 0.62. Gerombol A1 terdiri dari aksesi Ph. gigantea A dan Ph. bellina yang menggerombol berdasarkan kemiripan bentuk daun, susunan daun, bentuk tepi daun, simetri daun dan tekstur daun. Kedua aksesi ini dapat dikatakan memiliki kemiripan sebesar $86 \%$. Gerombol A2 terdiri dari aksesi Ph. tetraspis, $P h$. amabilis Trenggalek dan $P h$. gigantea B. Gerombol A2 menggerombol karena kemiripan beberapa sifat morfologi yaitu bentuk ujung daun, susunan daun, bentuk tepi daun, simetri daun dan tekstur permukaan daun.

Tanaman pada aksesi Phalaenopsis tetraspis membentuk dua kelompok berbeda. Pengelompokan pada satu aksesi ini terjadi karena perbedaan bentuk ujung daun dimana tiga tanaman memiliki ujung daun berbentuk lancip sedangkan 
dua tanaman lainnya memiliki bentuk ujung daun memotong. Perbedaan bentuk ujung daun dapat dipengaruhi oleh perbedaan tempat tumbuh antara tanaman pada Phalaenopsis tetraspis. Tiga tanaman Phalaenopsis tetraspis dikoleksi di Bogor dan dua tanaman lainnya dikoleksi di Cipanas, Jawa Barat. Menurut Hardiyanto et al. (2007) terdapat sifat-sifat tanaman yang dipengaruhi oleh perubahan lingkungan (nutrisi, suhu, kelembaban dan iklim). Secara umum geografi dan ekologi yang luas dari populasi merupakan hal pertama yang menyebabkan perubahan-perubahan morfologi. Menurut Allard (1960) variasi sifat fenotip disebabkan oleh kerjasama antar genotip dan keadaan lingkungan.

$P h$. amabilis Trenggalek dan Ph. gigantea B mengelompok terlebih dahulu sebelum mengelompok pada gerombol A2. Hal ini karena kedua aksesi ini memiliki kemiripan pada semua parameter pengamatan sifat morfologi daun kecuali bentuk daun. Aksesi yang tergabung dalam gerombol A2 memiliki tingkat kemiripan $80 \%$.

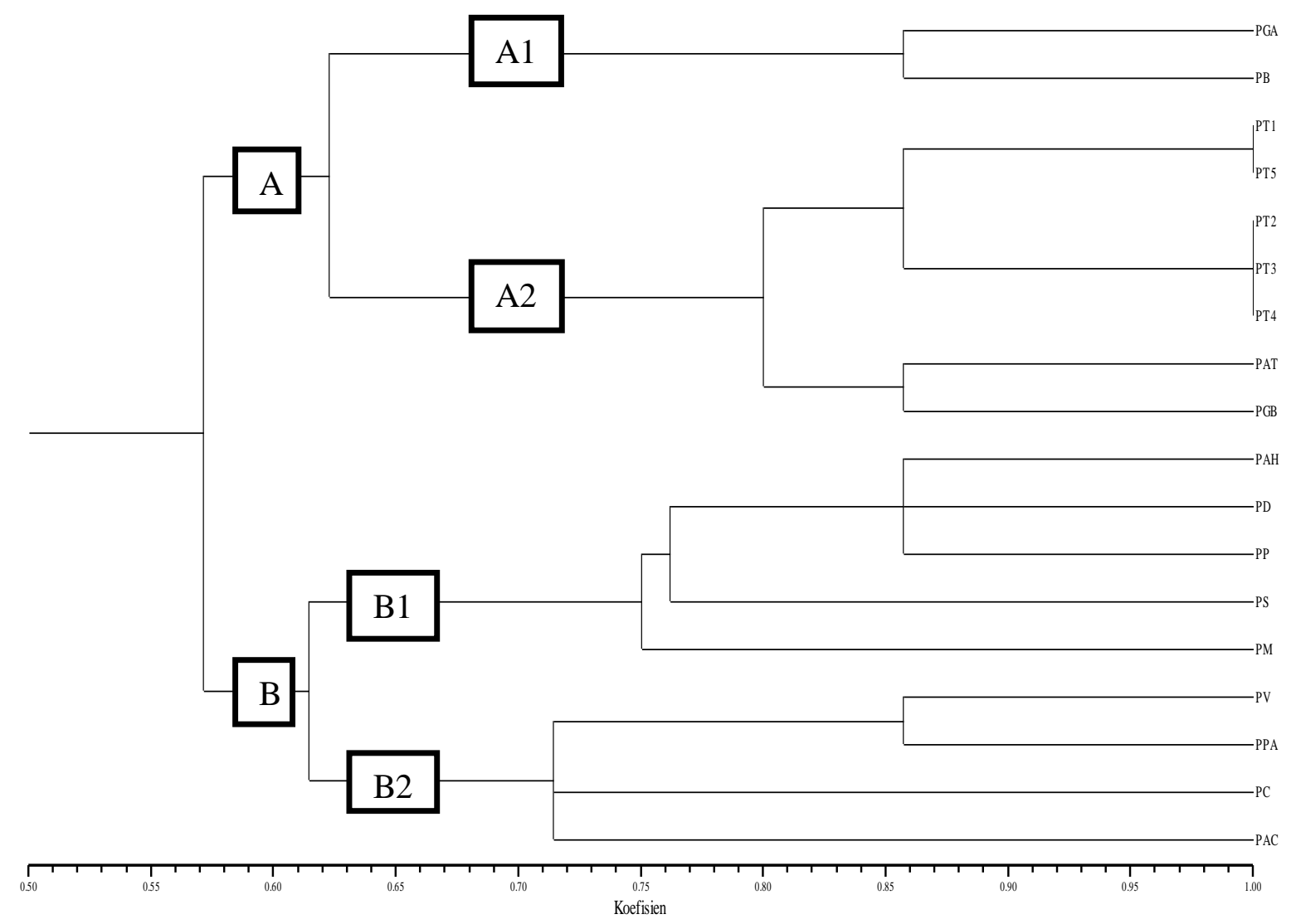

Gambar 1. Dendogram 67 tanaman anggrek Phalaenopsis spesies berdasarkan karakter morfologi pada daun

Gerombol B memiliki anggota yang lebih banyak dibandingkan dengan gerombol A. Aksesi yang tergabung dalam gerombol $\mathrm{B}$ adalah $P h$. violacea, Ph. pulchra, Ph. cornu-cervi, Ph. amabilis Cidaun, Ph. schillerian, Ph. amabilis Halong, Ph. doritis, Ph. pantherina dan $P h$. modesta. Karakter yang menjadikan 9 aksesi ini tergabung dalam gerombol B adalah susunan daun, bentuk tepi daun dan tekstur permukaan daun.

Terjadi pengelompokan pada gerombol B menjadi B1 dan B2 pada jarak euclidius 0.61. $P h$. amabilis Halong, Ph. doritis dan Ph. pantherina terlebih dahulu mengelompok pada jarak eucliduis 0.86 artinya ketiga aksesi tersebut memiliki tingkat kemiripan $86 \%$ yang disebabkan oleh kemiripan pada beberapa karakter morfologi yaitu bentuk ujung daun dan simetri daun. Selanjutnya $P h$. amabilis Halong, Ph. doritis dan Ph. pantherina mengelompok dengan $P h$. schilleriana membentuk gerombol B2 kelompok I pada jarak euclidius 0.76 artinya empat aksesi tersebut memiliki tingkat kemiripan $76 \%$ dengan karakter morfologi penyebab kemiripan adalah simetri daun. Kelompok II pada gerombol B terdiri dari 1 aksesi yaitu $P h$. modesta dengan karakter yang membedakannya adalah bentuk ujung daun. Aksesi pada gerombol B1 memiliki tingkat kemiripan sebesar 75\%. 
Gerombol B2 membentuk tiga kelompok pada jarak euclidius 0.71 . Ph. violacea dan $P h$. pulchra merupakan anggota kelompok I, namun kedua aksesi ini memiliki perbedaan pada karakter bentuk daun yang menyebabkan kedua aksesi terpisah menjadi sub kelompok sehingga tingkat kemiripannya adalah $86 \%$. Anggota kelompok II dan III berturut-turut adalah aksesi Ph. cornu-cervi dan Ph. amabilis Cidaun. Ketiga kelompok ini memiliki tingkat kemiripan $71 \%$ dengan karakter kemiripannya yaitu susunan daun, bentuk tepi daun dan tekstur permukaan daun. Kartikaningrum et al. (2002) dalam penelitiannya mengenai kekerabatan 13 spesies anggrek berdasarkan data fenotipik menunjukkan bahwa anggrek Phalaenopsis doritis, Phalaenopsis amabilis dan Phalaenopsis violacea mengelompok pada jarak euclidius 0.71 dengan koefisien muali dari 0.601.00 .

Berdasarkan analisis gerombol yang ditunjukkan dengan dendogram pada Gambar 1, tanaman yang berasal dari aksesi yang sama memiliki tingkat kemiripan $100 \%$ atau berada pada jarak euclidius 1.00. Menurut Purwantoro et al. (2005) dalam penelitiannya mengenai kekerabatan antar anggrek spesies berdasarkan sifat morfologi tanaman dan bunga, hasil analisis gerombol memperlihatkan bahwa anggrek yang berasal dari satu genus yang sama belum tentu memiliki kekerabatan yang lebih dekat. Menurut Surahman et al. (2009) perbedaan karakter antar aksesi yang besar akan memberikan peluang yang baik dalam kegiatan seleksi.

\section{Pendugaan Hubungan Kekerabatan Berdasarkan Morfologi Bunga}

Pendugaan hubungan kekerabatan berdasarkan morfologi bunga dilakukan pada 8 aksesi anggrek Phalaenopsis spesies, yaitu $P h$. gigantea A, Ph. tetraspis, Ph. amabilis Cidaun, $P h$. bellina, Ph. schilleriana, Ph. violacea, Ph. modesta dan Ph. cornu-cervi. Perbedaan jumlah aksesi pada pengamatan daun dan bunga karena pada saat dilakukan penelitian ini tidak semua aksesi yang menjadi bahan tanaman berbunga. Hubungan kekerabatan anggrek Phalaenopsis spesies berdasarkan morfologi bunga ditunjukkan pada dendogram (Gambar 2).

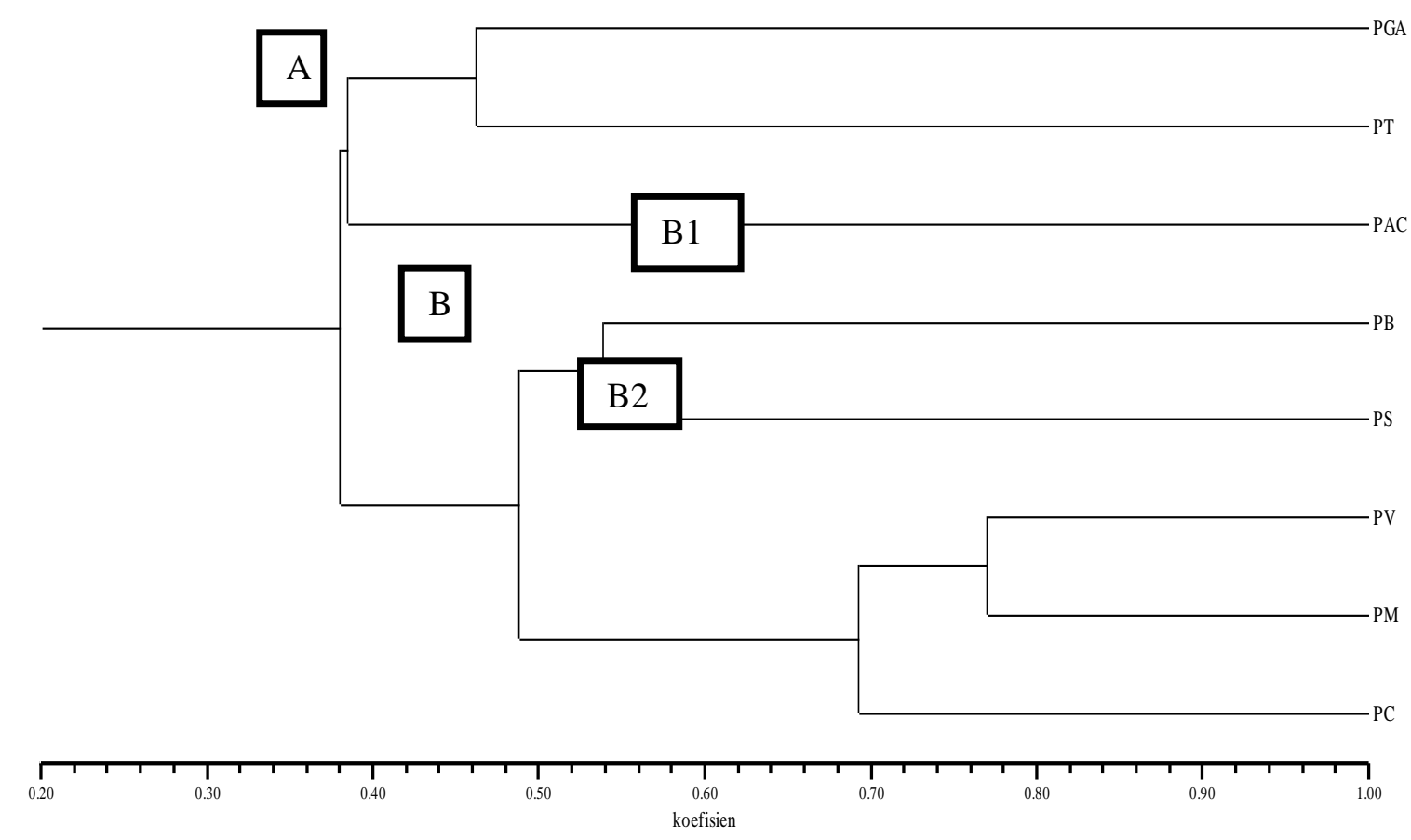

Gambar 2. Dendogram 8 aksesi anggrek Phalaenopsis spesies berdasarkan karakter morfologi pada bunga

Berdasarkan analisis gerombol pada karakter morfologi bunga, 8 aksesi anggrek Phalaenopsis spesies membentuk dua gerombol yaitu A dan B pada jarak euclidius 0.38 . Gerombol A terdiri dari Ph. gigantea A, Ph. tetraspis dan Ph. amabilis Cidaun yang mengelompok berdasarkan kemiripan 
pada penampang melintang sepal dan petal. $P h$. gigantea A dan Ph. tetraspis mengelompok terlebih dulu pada jarak euclidius 0.46 sebelum menjadi gerombol A dengan $P h$. amabilis Cidaun. Hal ini karena Ph. gigantea A dan Ph. tetraspis memiliki kesamaan pada bentuk bunga, bentuk sepal, bentuk petal dan penampang membujur sepal.

Gerombol B terdiri dari $P h$. bellina, $P h$. schilleriana, Ph. violacea, Ph. modesta dan Ph. cornu-cervi yang menggerombol pada jarak euclidius 0.48 atau memiliki tingkat kemiripan $48 \%$. Karakter penyebab kemiripannya adalah tipe pembungaan, penampang melintang sepal, penampang melintang petal dan susunan petal. Anggota gerombol B terlebih dulu membentuk kelompok B1 dan B2. Kelompok B1 yaitu $P h$. bellina dan $P h$. schilleriana mengelompok pada jarak euclidius 0.54 berdasarkan kemiripan resupinasi dan bentuk sepal dorsal.

Kelompok B2 mengelompok pada jarak euclidius 0.69 yang terdiri dari Ph. violacea, $P h$. modesta dan Ph. cornu-cervi. Ketiga aksesi ini mengelompok karena persamaan karakter tipe pembungaan, bentuk bunga dan bentuk sepal lateral. $P h$. violacea dan $P h$. modesta mengelompok terlebih dulu sebelum bergabung dengan $P h$. cornu-cervi. Hal ini terjadi karena perbedaan bentuk ujung sepal dan petal antara $P h$. violacea dan Ph. modesta dengan Ph. cornu-cervi.

Fatimah et al. (2010) dalam penelitiannya mengenai studi filogenetik dan identifikasi molekuler anggrek Phalaenopsis sp. menggunakan marka microsatelit menunjukkan bahwa Phalaenopsis sp. berdasarkan 12 primer mikrosatelit membagi menjadi 4 gerombol, dimana Phalaenopsis bellina dan Phalaenopsis schilleriana berada dalam satu gerombol dan Phalaenopsis modesta dengan Phalaenopsis cornu-cervi berada pada satu gerombol berbeda.

\section{Pendugaan Hubungan Kekerabatan Berdasarkan Morfologi Daun dan Bunga}

Pendugaan hubungan kekerabatan dilakukan dengan menggabungkan sifat morfologi daun dan bunga beberapa aksesi anggrek Phalaenopsis spesies yang selanjutnya disajikan dalam dendogram (Gambar 3).

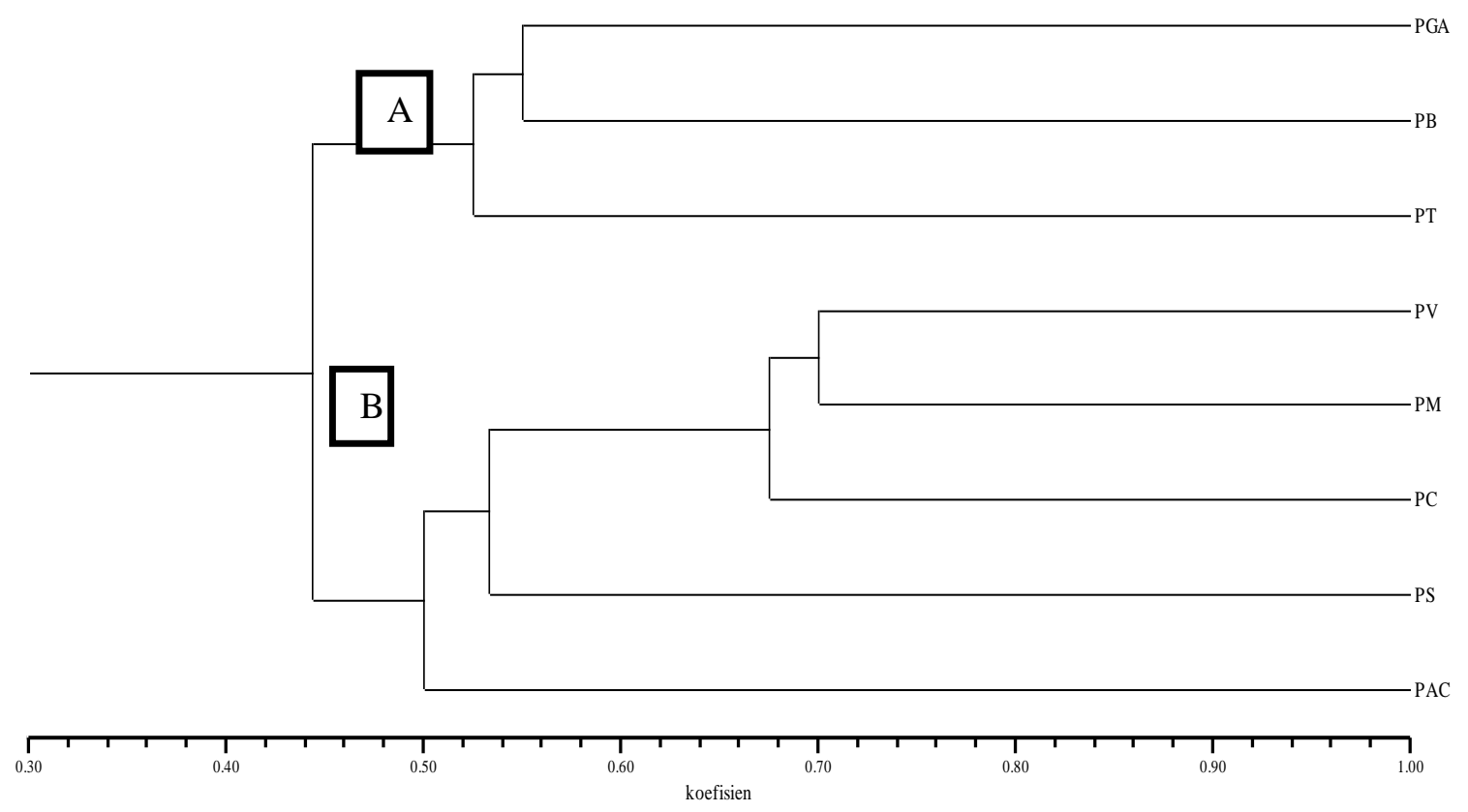

Gambar 3. Dendogram aksesi anggrek Phalaenopsis spesies berdasarkan karakter morfologi pada daun dan bunga

Pendugaan hubungan kekerabatan dilakukan dengan mengelompokkan Phalaenopsis kedalam tiga kelompok berdasarkan morfologi daun, bunga serta daun dan bunga melalui analisisi gerombol menghasilkan beberapa perbedaan. Pendugaan dengan karakter morfologi daun menunjukkan bahwa Phalaenopsis gigantea A berada dalam satu gerombol dengan Phalaenopsis bellina dan Phalaenopsis tetraspis, sedangkan pada analisis gerombol berdasarkan karakter morfologi bunga Phalaenopsis gigantea A masih berada dalam satu gerombol dengan Phalaenopsis 
tetraspis namun terpisah dengan Phalaenopsis bellina. Ketiga aksesi ini menjadi satu gerombol kembali pada pendugaan berdasarkan karakter morfologi daun dan bunga, sehingga dapat disimpulkan bahwa ketiga aksesi tersebut memiliki kemiripan yang lebih tinggi pada karakter morfologi daun.

Perbedaan lain terjadi pada Phalaenopsis amabilis Cidaun yang berada dalam satu gerombol dengan Phalaenopsis violacea, Phalaenopsis cornu-cervi, Phalaenopsis schilleriana dan Phalaenopsis modesta pada pendugaan berdasarkan karakter morfologi daun, sedangkan pada pendugaan berdasarkan karakter morfologi bunga Phalaenopsis amabilis Cidaun berada dalam satu gerombol dengan Phalaenopsis gigantea A dan Phalaenopsis tetraspis. Pendugaan dengan menggabungkan karakter morfologi daun dan bunga menunjukkan kembali bahwa kelima aksesi tersebut berada dalam satu gerombol meskipun terpisah menjadi beberapa kelompok karena beberapa sifat spesifik dari masing-masing aksesi. Karakter morfologi daun dan bunga merupakan karakter yang digunakan sebagai penanda untuk membedakan kelompok pada tanaman anggrek (Bechtel et al. 1981).

\section{Analisis Stomata}

Analisis stomata dilakukan untuk mengetahui kerapatan dan ukuran stomata pada daun beberapa aksesi anggrek Phalaenopsis spesies. Pengamatan hanya dilakukan pada aksesi
Ph. schilleriana, Ph. cornu-cervi, Ph. tetraspis dan $P h$. amabilis Cidaun, hal ini dilakukan karena keterbatasan bahan tanaman akibat terserang penyakit busuk daun pada saat pelaksanaan penelitian.

Stomata diamati pada permukaan daun bagian bawah. Menurut Sutrian (1992) pada daun yang berwarna hijau, stomata akan terdapat pada kedua permukaannya atau kemungkinan pula hanya terdapat pada suatu permukaannya saja yaitu pada permukaan bagian bawah.

Berdasarkan pengamatan di bawah mikroskop, tampak bahwa stomata pada daun anggrek Phalaenopsis spesies yang diamati berbentuk ginjal dan letaknya tidak teratur. Menurut Sutrian (1992) pada kebanyakan tumbuhan kecuali Gramineae dan Cyperaceae sel penjaga secara umum berbentuk ginjal. Daun dengan sistem pertulangan menjala, stomata menyebar tidak teratur sedangkan pada daun dengan sistem pertulangan sejajar seperti Gramineae, stomata tersusun dalam barisan yang sejajar.

Ukuran stomata ditentukan dengan melakukan pengukuran panjang dan lebar stomata. Stomata yang memiliki ukuran terpanjang dan terlebar adalah stomata aksesi Phalaenopsis cornu-cervi, sedangkan aksesi yang memiliki ukuran stomata terkecil adalah Phalaenopsis modesta. Data ukuran stomata dan kerapatan stomata tersaji pada Tabel 3.

Tabel 3. Rata-rata panjang, lebar dan kerapatan stomata anggrek Phalaenopsis spesies

\begin{tabular}{lccc}
\hline \multicolumn{1}{c}{ Aksesi } & $\begin{array}{c}\text { Panjang } \\
(\mathrm{nm})\end{array}$ & $\begin{array}{c}\text { Lebar } \\
(\mathrm{nm})\end{array}$ & Kerapatan stomata $\left(\mathrm{mm}^{-2}\right)$ \\
\hline Ph. schilleriana & 24444.23 & 18630.02 & 32.27 \\
Ph. cornu-cervi & 28050.61 & 22096.03 & 50.96 \\
Ph. tetraspis & 17742.57 & 13986.88 & 27.18 \\
Ph. amabilis Cidaun & 24705.19 & 18717.1 & 23.78 \\
Ph. modesta & 13949.43 & 12552.52 & 18.68 \\
\hline
\end{tabular}

Menurut Damayanti (2007) ukuran sel epidermis dan stomata berhubungan dengan tingkat ploidi. Pisang aksesi AK8P dengan tingkat ploidi triploid mempunyai ukuran sel epidermis dan stomata lebih besar daripada aksesi lainnya. Ukuran sel epidermis dan stomata pada permukaan atas daun lebih besar daripada permukaan bawah. Rata-rata kerapatan stomata tertinggi adalah aksesi Phalaenopsis cornu-cervi dan yang terendah adalah Phalaenopsis modesta. Fitriani et al. (2006) menyebutkan bahwa kerapatan stomata yang menurun menyebabkan jumlah stomata pada bidang pandang menjadi sedikit, namun hal ini memperlancar transpirasi sehingga penyerapan air untuk pertumbuhan tanaman meningkat.

\section{KESIMPULAN}

Karakter kuantitatif pada daun dan bunga Phalaenopsis spesies menunjukkan nilai yang beragam. Hasil analisis statistik dengan uji tdunnet menunjukkan beberapa karakter yang tidak 
berbeda nyata dengan $P h$. amabilis Cidaun sebagai kontrol adalah jumlah daun, panjang daun $P h$. gigantea A, Ph. amabilis Trenggalek dan $P h$. gigantea B. Karakter pada bunga yang tidak berbeda nyata dengan kontrol adalah panjang bunga $P h$. violacea dan $P h$. schilleriana, panjang sepal dorsal semua aksesi kecuali Ph. modesta, panjang sepal lateral $P h$. violacea, lebar sepal lateral semua aksesi kecuali $P h$. cornu-cervi dan lebar petal Ph.schilleriana.

Setiap anggota masing-masing aksesi pada Phalaenopsis spesies memiliki kekerabatan sangat dekat yaitu $100 \%$ kecuali $P h$. tetraspis yang berkerabat $87 \%$ akibat perbedaan bentuk ujung daun. Berdasarkan klasifikasi daun aksesi yang berkerabat dekat adalah $P h$. gigantea A dengan Ph. bellina (87\%), Ph. amabilis Trenggalek dengan Ph. gigantea B (87\%), Ph. violacea dengan Ph. pulchra (87\%) dan Ph. amabilis Halong dengan $P h$. pantherina $(87 \%)$.

Berdasarkan klasifikasi bunga aksesi yang memiliki kekerabatan dekat adalah Ph.violacea dengan Ph. modesta (78\%), sedangkan berdasarkan klasifikasi daun dan bunga aksesi yang berkerabat dekat adalah $P h$. violacea dengan Ph. modesta (70\%).

\section{DAFTAR PUSTAKA}

Allard, R.W. 1960. Pemuliaan Tanaman. Bandung (ID): Rineka Cipta.

Bechtel, H., Cribb P., Launnert E. 1981. The Manual of Cultivated Orchid Species. 1981. Poole Dorset (UK): Blanddford Pess.

Damayanti, F. 2007. Analisis jumlah kromosom dan anatomi stomata pada beberapa plasma nutfah pisang (musa sp.) asal Kalimantan Timur. Bioscientiae. 4(2):53-61.

Fatimah, Sukma D. 2010. Studi filogenetik dan identifiasi molekuler anggrek Phalaenopsis sp. menggunakan marka microsatelit. Prosiding Seminar Nasional Hortikultura Indonesia 2010, Perhimpunan Hortikultura Indonesia [Internet]. Universitas Udayana, Bali (ID). Tersedia di http://repository.ipb.ac.id/handle/123456789 158481. [15 Juni 2013].

Fitriani, V., Haryanti S., Darmanti S. 2006. Hubungan antara jarak tanam dari kawah
Sikidah Dieng dengan ukuran dan jumlah stomata daun tanaman kentang (Solanum tuberosum L). Bull Anatomi dan Fisiologi. 14(2):47-55.

Hardiyanto, Mujiarto E., Sulasmi E.S. 2007. Kekerabatan genetik beberapa spesies jeruk berdasarkan taksonometri. J. Hort. 17(3):203-216.

Irawan, B., Purbayanti K. Karakterisasi dan kekerabatan kultivar padi lokal di desa Rancakalong kecamatan Rancakalong kabupaten Sumedang. Seminar Nasional PTTI [Internet]. Bandung; 21-23 Oktober 2008. Bandung, Indonesia. Tersedia di http://pustaka.unpad.ac.id/wpcontent/upload s/2010/05/karakteristik_dan_kekerabatan_k ultivar padi lokal.pdf. [15 Juni 2013].

Jenny, J., Rondonuwu, D.D. Pioh. 2009. Kebutuhan hara tanaman hias anggrek. Soil environment. 7(1):73-79.

Kartikaningrum, S., Hermiati N., Baihaki A., Haeruman M., Matius N.T. 2002. Kekerabatan antar genus anggrek sub tribe Sarcanthinae berdasarkan data fenotip dan pola pita DNA. Zuriat. 13(1):1-10.

Marzuki, I., Uluputty M.R., Aziz S.A., dan Surahman M. 2008. Karakterisasi morfoekotipe dan proksimat pala banda (Myristica fragrans Houtt.). Bul Agron. 36(2):145-151.

Mattjik, N.A. 2010. Budi Daya Bunga Potong dan Tanaman Hias. Purwito A, editor. Bogor (ID): IPB Press.

Purwantoro, A., E. Ambarwati, F. Setyaningsih. 2005. Kekerabatan antar anggrek spesies berdasarkan sifat morfologi tanaman dan bunga. Ilmu Pertanian 12 (1): 1-11.

Surahman, M., Santosa E., Nisya F.N. 2009. Karakterisasi dan analisis gerombol plasma nutfah jarak pagar Indonesia dan beberapa negara lain menggunakan marka morfologi dan molekuler. J. Agron. Indonesia. 37(3):256-264.

Sutrian, Y. 1992. Pengantar Anatomi Tumbuhtumbuhan. Bandung (ID): Rineka Cipta. 